\title{
A STUDY ON THE INFLUENCE OF KOREAN MIDDLE SCHOOL STUDENTS' RELATIONSHIP THROUGH SCIENCE CLASS APPLYING STAD COOPERATIVE LEARNING
}

\author{
Dongryeul Kim 1 \\ Daegu National University of Education (Republic of Korea) \\ dongryeulk@gmail.com
}

Received February 2018

Accepted May 2018

\section{Abstract}

In order to find out the influence of Korean Middle School Students' relationship by science class applying STAD cooperative learning, this study conducted a social network analysis and sought to analyze the communication networks within the group and identified the change process of the type. The subject of this study was 30 students of the second grade at the girls' middle school located in Korea's Metropolitan City. For five weeks, science class applying STAD Cooperative Learning was implemented in the 'reproduction and generation' chapter. First, the class social network analysis showed that all the prices of density, degree centrality, closeness centrality, and betweenness centrality have risen after science class applying STAD Cooperative Learning. Also, the classroom's relationship index has improved. In other words, STAD Cooperative Learning encouraged interaction among students. Second, in order to research popularity, students' centrality analysis through the class social network analysis showed that top-ranked students' values of density, degree centrality, closeness centrality, and betweenness centrality appeared commonly high after science class applying STAD Cooperative Learning. Third, the analysis of the communication network change within six groups showed that all channel type appeared most often and circle type also appeared anew after science class applying STAD Cooperative Learning. In other words, it was possible to exchange information freely and communicate with all members of the group through STAD Cooperative Learning.

Keywords -STAD cooperative learning, Relationship, Social network, Science class.

\section{Introduction}

Vygotsky (1978) argued that the learning process was facilitated by the participation of individuals in social interactions through the process of assisting members. Such a viewpoint implies that cooperative activities should be made to focus on encouraging learners to support the sharing of information and resources. However, the test competition of Korea's academic education is causing intense rivalry among friends, causing a negative attitude toward friendship, and causing tension and pressure to prevent whole-minded human (Kim \& Kim, 2010). At this point, peer relations are important in the school community, and as students mostly learn through their peer relations, what kinds of peer relations they have greatly affect their learning performances.

In science class, especially to facilitate interaction among learners, group activities such as experimental activities, discussion and decision-making activities are emphasized (Yang, Le, Oh, Jeong, Kwon \& Park, 2007). Research activities in science class consist of numerous observations and experimental activities, and to effectively perform them, interaction between members of the team should be encouraged as group activities (Park \& Shin, 2012). 
In science learning, cooperation and interaction are not merely strategies for teaching, but also learning objectives that should be achieved. Cooperation is important because science teachers attempt to teach students more learning materials in a culturally and linguistically diverse classroom, and in a comprehensive classroom environment (Doran, Doran \& Mazur, 2011).

Cooperative learning is an active learning process because students learn more by creating and sharing knowledge in groups. Cooperative learning can provide students with the opportunity of discussion and help students develop essential social skills (Khan \& Inamullah, 2011). Through these activities, students will have courage and critical thinking and are willing to take responsibility for their own learning. A typical form of cooperative learning is Students Team Achievement Divisions, a method of solving the problem in groups and a way to motivate you to actively learn (Sukma, 2013). Slavin (1978) presented STAD (Student Teams-Achievemnet Division) Model for the first time, and since then, this model has been applied to various themes in fields of mathematics, linguistics, art, sociology and science (Karaçöp, 2016). Slavin (1980) defined this model as an effective learning method in a class circumstance that students carry out learning activities as a team and receive rewards and recognitions based on their team scores. Besides, since it is a one of the simplest cooperative learning methods, STAD has been assessed as a good model when teachers intend to apply cooperative learning for the first time (Maelasari \& Wahyudin, 2017; Slavin, 1990). STAD is one of Cooperative Learning strategies that help promote learning skills of cooperation and self-controlment (Rai \& Samsuddin, 2007). In STAD, a group is composed of 4 or 5 students who have good academic skills and poor academic skills. They cooperate to improve quiz scores after answering individual quiz, and every member of the group is responsible for the overall members' enhancement to achieve the best group with the highest academic achievement.

These traits suggest that analyzing relationships between the related patterns caused by learners' interaction through STAD cooperative learning has important implications in science learning, which emphasizes the importance of collective activities.

Social networking analysis, meanwhile, shows the exchange of resources among social interaction subjects and help establish their positive relationships of how these interactions relate (Haythornthwaite, 2002). By analyzing social networks, it is possible to visually find out correlations between organization members and their interactions and social positions through the map, which are generated when they participate in social activities (Freeman 2000). Since the formation of cohesive social networks is essential for effective social learning, the formation and structure of these social networks rather than analyzing a social phenomenon or organization is distinguished from the doer-centered approach or the variable-oriented approach in the context of emphasizing the emerging properties derived from relationships and analyzing the aspects of the relationship accordingly (Choi, 2011; Dawson, 2008).

When considering student experience related with interaction and cooperation, social networking analyses provide useful ways for research and analysis. The interactions between individuals involved in the network, especially the number of each member who interacts with each other, how important each member of the network is, and how many members of the group are formed is a means to identify patterns of variables (Doran et al., 2011). The structural nature of a social network can be explained by the magnitude of the network, network density, and centrality, and these indicators help to understand the relationships of doers who form the network (Choi, 2011). Various measurements on the centrality include degree centrality (the number of relationships each subject has in the network), closeness centrality (measuring the direct and indirect relationships between group members), and betweenness centrality (measuring a way to assist how each member can relate to other members of the network.).

Analyzing social networking are also applied to community studies to examine social relationships and patterns evolving through members of the Members' interaction (Cho, Lee, Stefanone \& Gay, 2005). An important reason for analyzing the communication network in cooperative learning is that being organized by groups' features rather than individuals' characteristics is more compatible with the purpose of collective learning which focuses on group activities and cooperative outcomes (Kim \& Park, 2008). In particular, as forming groups for communication type matched with cooperative learning, learning 
effectiveness can increase and it can increase the effectiveness of learning by diversifying the tasks and activities of cooperation learning based on the type of communication (Kim \& Park, 2008). Since Bavelas and Barrett (1951) studied the collective effectiveness of communication networks and suggested five basic types of communication networks : chain, wheel, Y-shaped, circle, all channel, many researchers have revealed the relationship between the communication patterns and the activity of the small group (Huh \& Lee, 2010).

In school society, even though social relationships have more important significance in society, so far most cooperative learning study mainly focus on researches of small groups' learning effectiveness consisting of homogeneous groups or heterogeneous groups solely based on academic achievement, and a study of cooperative learning considering friendship is insufficient. Therefore, a study on the relationship to achieve common learning objectives and useful learning results need to be conducted through small group cooperative interaction by a desirable interaction among students.

In this study, to reveal STAD cooperative learning's effect of middle school students' relationship, a social network and communication networks within the group are analyzed and the type of change process is revealed.

The research questions set out under the objectives of this study are as follows:

- First, how does a science class with STAD Cooperative Learning affect the changes in the shape and characteristics of the relationship network?

- Secondly, what is the characteristics and the behavior features of a popular student in the science class that applied STAD?

- Third, how does the science class that applied STAD affect the type change of communication network within a group?

\section{Method}

\subsection{Research Object}

The subject of this study was 30 students of the second grade at the girls' middle school located in Korea's Metropolitan City. The science teacher' classroom as the homeroom teacher is selected. The reason is that my homeroom teacher is good at understanding the students, and students respond to questions of a questionnaire taught by their homeroom teacher, which can reduce the burden and explains about the result by students' post-interviews. In Korea, a homeroom teacher is fully in charge of one class and plays a role in instructing and guiding his or her students' school life. This study is not to comparatively analyze results by gender, and as all the classes instructed by science teachers participating in this research were composed of female students only, this study had to select female students only as research subjects.

\subsection{Science Classes Applying STAD Cooperative Learning}

This study focused on the 1 2 subjects based on learning contents ranging from 2 to 3 period per week throughout the total 11 th period, and the 'reproduction and generation' chapter was implemented for five weeks (In Korea, science is taught two or three times per week at middle schools, and every science class lasts 45 minutes. Therefore, ' 2 sessions of science' means carrying out the 45 minutes-lasting science class twice.). Science classes with STAD cooperative learning was conducted by a science teacher with 12 years teaching experience as new materials should be presented to students in the form of discussions and skilled teaching methods.

The courses in the STAD Cooperative Learning consist of class introduction, small group activities, assessment, individual's and small group's improvement grades, small group scores posting and rewards. Specific activities for each step shall be as shown in Table 1. 


\begin{tabular}{|c|c|}
\hline Class Step & ctivities contents \\
\hline $\begin{array}{l}1 \text { STEP } \\
\text { Class } \\
\text { Introduction } \\
\text { (20 minute) }\end{array}$ & $\begin{array}{l}\text { Provide scientific knowledge under the guidance of teachers } \\
\text { Ask specific questions frequently to make sure that students understand. } \\
\text { Provide explicit learning objectives when starting learning. } \\
\text { Use various learning materials to understand students' learning content. } \\
\text { Guide the small groups activities. }\end{array}$ \\
\hline $\begin{array}{l}2 \text { STEP } \\
\text { Small Group } \\
\text { Activities } \\
\text { (20 minute) }\end{array}$ & $\begin{array}{l}\text { Constitute heterogeneous organization considering a small group of students' ability to study } \\
\text { (Make } 6 \text { group consisting of five out of } 30 \text { people, and in order for each subgroup to achieve the } \\
\text { same level of achievement, assign A to F from top student and next, assign from F to A.). } \\
\text { In STAD class, explain the set of rules that students should follow and attach them to class } \\
\text { boards and all the students follow them. } \\
\text { Create group names and team slogans to form unity and teamwork. } \\
\text { In addition to the laboratory's activities, when performing activities in the classroom, the } \\
\text { arrangement of the desks ensures interaction with students facing each other in the same group. } \\
\text { After class, distribute each part of workbooks (which clean up the contents of the class) } \\
\text { separately to each member of the class. } \\
\text { Students discuss problems together, compare answers, and go through the process of correcting } \\
\text { the misconceptions of a bunch of Members. They explain each other's processes and methods. } \\
\text { Students should ensure that the same group has learned all of the workbooks, and not all of } \\
\text { them should complete the study before everyone knows the lesson. } \\
\text { The teacher patrol around the classroom, praise the classroom and observe how well the } \\
\text { members of each group are doing and how well they perform. }\end{array}$ \\
\hline $\begin{array}{l}3 \text { STEP } \\
\text { Assessment } \\
\text { (5 minute) }\end{array}$ & $\begin{array}{l}\text { After the group ends, quiz questions will be given to individuals. } \\
\text { Workbooks were organized based on the contents sequence of "reproduction and generation" } \\
\text { chapter, and the quiz is constructed similarly with the workbooks problem to increase the } \\
\text { participation of the group. } \\
\text { Ask about five questions per period as a simple subjective question format (constructed-response } \\
\text { item). } \\
\text { Evaluate the timing of the assessment properly considering the entire duration of the class. } \\
\text { During a quiz session, each team does not discuss each other individually, and each individual } \\
\text { solves the quiz individually. }\end{array}$ \\
\hline $\begin{array}{l}4 \text { STEP } \\
\text { Individual and } \\
\text { small group } \\
\text { improvement } \\
\text { score }\end{array}$ & $\begin{array}{l}\text { Teachers mark quiz grades outside of class. } \\
5 \text { quiz has two points per question and make a perfect score of } 10 \text {. } \\
\text { Give each student a basic grade and draw out the criteria based on the average score about the } \\
\text { formation evaluation of the entire unit. } \\
\text { Students earn additional improved scores on the base score for a group. } \\
\text { The role of individual students was determined by how many each student's quiz scores were } \\
\text { improved by their past average scores, or their current scores based on each student's quiz score } \\
\text { and the student's learning history. } \\
\text { Make group score including individual improvement scores by adding improvement scores to } \\
\text { group members. } \\
\text { (Give } 0 \text { point in the case of } 5 \text { points or lower than the reference score, give } 10 \text { points in the case } \\
\text { of } 1 \text { to } 5 \text { score lower than the reference score, give } 20 \text { points in the case of } 0 \text { to } 5 \text { score higher } \\
\text { than the reference score, give } 30 \text { points in case of more } 5 \text { score higher than the reference score.) } \\
\text { Post a note of the improvement scoring method on the bulletin board beforehand so that } \\
\text { students can understand the contribution of their scores. }\end{array}$ \\
\hline $\begin{array}{l}5 \text { STEP } \\
\text { Post Small } \\
\text { group scores } \\
\text { and rewards }\end{array}$ & $\begin{array}{l}\text { Group scores will be posted on the class board after class. } \\
\text { Team with the most group scores } \\
\text { Give the team members nickname of life science doctor, some snacks, and a little bit of } \\
\text { performance evaluation plus score, and give the second team nickname of life science doctor, } \\
\text { some snacks. } \\
\text { Record each team's average score at group scorecard in each period. }\end{array}$ \\
\hline
\end{tabular}

Table 1. STAD Cooperative Learning Activities Contents 


\begin{tabular}{|c|c|c|c|}
\hline Unit & Period & Topics & Class Contents \\
\hline \multirow{4}{*}{ Cell division } & $1-2$ & $\begin{array}{l}\text { How does body } \\
\text { cell divide? }\end{array}$ & $\begin{array}{l}\text { Understand the meaning of growth } \\
\text { To test the relationship between surface and volume of cells } \\
\text { Understanding mitosis process } \\
\text { [Quiz Problem Example] There is a picture of mitosis in some animals. } \\
\text { Let's list the division process of mitosis in order. Let's explain why cells } \\
\text { should divide. }\end{array}$ \\
\hline & 3 & $\begin{array}{l}\text { What role does } \\
\text { the } \\
\text { chromosome } \\
\text { play? }\end{array}$ & $\begin{array}{l}\text { Arrange human chromosome } \\
\text { Understanding the concepts of homophilic chromosome, autosomal, and } \\
\text { sex chromosomes } \\
\text { [Quiz Problem Example] Where is the chromosome located in the cell? } \\
\text { How does the sex chromosome of men and women represent each other? }\end{array}$ \\
\hline & 4 & $\begin{array}{l}\text { How are } \\
\text { reproductive } \\
\text { cells created? }\end{array}$ & $\begin{array}{l}\text { Understanding the division process of reproduction cell } \\
\text { Comparison of Chronological Changes in Somatic Mitosis and Germinal } \\
\text { cell division } \\
\text { [Quiz Problem Example] What is said to be homophilic chromosome that } \\
\text { is paired together and attached to each other? } \\
\text { During the division of reproductive cells, what is the period in which the } \\
\text { number of chromosomes decreases in meiosis } 1 \& 2 \text {. }\end{array}$ \\
\hline & 5 & $\begin{array}{l}\text { How are } \\
\text { asexual } \\
\text { reproduction } \\
\text { and sexual } \\
\text { reproduction } \\
\text { different? }\end{array}$ & $\begin{array}{l}\text { Various methods of reproduction in living organisms } \\
\text { The merit of sexual reproduction } \\
\text { [Quiz Problem Example] How many offspring are born of asexual } \\
\text { reproduction or sexual reproduction? Let's explain how asexual } \\
\text { reproduction occurs in plants. }\end{array}$ \\
\hline \multirow[t]{2}{*}{$\begin{array}{l}\text { Fecundation } \\
\text { and } \\
\text { generation }\end{array}$} & $6-7$ & $\begin{array}{l}\text { How does the } \\
\text { fertilization and } \\
\text { generation of } \\
\text { plants occur? }\end{array}$ & $\begin{array}{l}\text { Observe the appearance of flowers } \\
\text { Pollen tube budding } \\
\text { Observe the fruit } \\
\text { [Quiz Problem Example] What are the two nucleus respectively fertilized? } \\
\text { How many times of a sperm nucleus is the number of albumen } \\
\text { chromosomes in an angiosperm? How many times of germinal vesicle's } \\
\text { body cell is the number of chromosomes in the an egg cell? }\end{array}$ \\
\hline & 8 & $\begin{array}{l}\text { What happens } \\
\text { to animal } \\
\text { fertilization and } \\
\text { development? }\end{array}$ & $\begin{array}{l}\text { Understanding Frog's fecundation and generation Process } \\
\text { [Quiz Problem Example] What is said to be the onset of early cell division } \\
\text { of the embryo? Let's list in order the number of pictures in the sequence } \\
\text { of the animal's fertilization process. }\end{array}$ \\
\hline \multirow{3}{*}{$\begin{array}{l}\text { Human } \\
\text { reproduction }\end{array}$} & 9 & $\begin{array}{l}\text { How is the } \\
\text { reproductive } \\
\text { system of men } \\
\text { and women } \\
\text { different? }\end{array}$ & $\begin{array}{l}\text { The structure and function of the reproductive organs of men and } \\
\text { women } \\
\text { Human sperm and egg } \\
\text { [Quiz Problem Example] Where is the pavilion that sperm is made? } \\
\text { Human eggs are smaller and less nutritious than chicken eggs. Why is the } \\
\text { human egg size smaller than the chicken egg? }\end{array}$ \\
\hline & 10 & $\begin{array}{l}\text { What is the } \\
\text { character of a } \\
\text { person's } \\
\text { reproductive } \\
\text { cycle? }\end{array}$ & $\begin{array}{l}\text { Female reproductive cycles and ovulation } \\
\text { Causes of infertility } \\
\text { [Quiz Problem Example] Painting represents a woman's reproductive } \\
\text { cycle. Let's find out about the reproductive cycles. How long does } \\
\text { menstruation last? About how many days does ovulation occur after } \\
\text { menstruation? In what sequence is the reproduction cycle performed? } \\
\text { What is the reproductive cycle? }\end{array}$ \\
\hline & 11 & $\begin{array}{l}\text { How does } \\
\text { pregnancy and } \\
\text { birth care } \\
\text { work? }\end{array}$ & $\begin{array}{l}\text { Human Fertilization and pregnancy } \\
\text { Fetal growth } \\
\text { The structure of the placenta and the substance exchange of the fetus } \\
\text { [Quiz Problem Example] Where is the fertilization of a sperm and egg } \\
\text { cell? Where does the fertilized egg come from? What pathways does the } \\
\text { fetus receive nutrients and oxygen from its parent? }\end{array}$ \\
\hline
\end{tabular}

Table 2. Science Class Contents Applying STAD Cooperative Learning 
"Reproduction and generation" chapter is one of the science contents where teachers and students find out the most difficult, and the content of reproduction including untested data through everyday life is one of the areas that lead to misconception (Kim, 2007). Also, because "reproduction and generation" is an important aspect of understanding life phenomena and establishing values for life, a fundamental concept, and a complex conceptual structure closely linked to other concepts, it is recognized as one of the most difficult chapters (Kim, Chu \& Kim, 2011). On the other hand, students are very interested in the topic of "reproduction and generation" and very low comprehension due to the difficulty of concept definition for reproduction can be attributed to the inadequacy of teaching methods (Kim, 2007). Therefore, learning about "reproduction and generation" through interacting with each other based on individual experiences in everyday life is necessary. Further, the selection of Unit Selection for Research also reflected teachers' opinions that a "reproduction and generation" chapter is appropriate for applying STAD cooperative learning.

Lessons from "reproduction and generation" were conducted in Korea's science textbook and class topics in reproduction and generation unit and detailed teaching materials are shown in Table 2.

\subsection{Survey Contents}

A peer nomination method was used to investigate the class social networks. A peer nomination method which the Moreno (1953) used was how to write a certain number of peer names based on some criteria by applying Name Generator Questions (NGQ: a questionnaire designed to identify and organize the names of the members corresponding to each question). Detailed questions such as "Would it be helpful to have a discussion with someone in science class?" explain the purpose (Relationship analysis of Scientific Class applying STAD Cooperative Learning) of the survey to accurately understand the meaning of the question statement and up to four people were configured to respond in consideration of the number of persons in a group. If possible, the names of four friends were written and students who did not write the names of four friends were included as one of the social networks analysis items within the class.

Along with the four names, the choice reasons related to scientific learning were also described. The completed questionnaire from the teacher and gathered it as a method to collect and collect materials. After a homeroom teacher's confirming whether a questionnaire was completely written, a homeroom teacher gathered it from students and collected data. Social network analysis requires that all classroom members participate in the survey and on the day of the survey, students who were excused or absent from science class were confirmed, and the purpose and methodology of the survey was explained to them and a questionnaire was completely written (Kim \& Kim, 2010). After questions were distributed to students, while writing the questionnaire, the students were unable to communicate with each other and were asked to respond with their real name. As a result of the analysis, it was expressed as an attendance number for the security of personal information. The fact that the result of the questionnaire is confidential was told to the students. The class social network survey was conducted once upon a pre- and post-scheduled Scientific Class applying STAD Cooperative Learning, respectively.

After analyzing social networks through questionnaire, to understand an in-depth context of an doer (a student) in addition to the structural characteristics of friends, 30 minutes were added to the interview with the homeroom teacher about the popular students based on analyzing the structure of social networks in Scientific Class applying STAD Cooperative Learning.

Finally, to find out how Scientific Class applying STAD Cooperative Learning affected changes in the communication network type within each group, a survey was conducted on "would it be helpful to have a discussion with someone in the same group?" The social network survey in group was conducted once upon a pre- and post-scheduled Scientific Class applying STAD Cooperative Learning, respectively.

\subsection{Analysis Method}

Data Analyses of friendships were conducted based on NetMiner 4.0 and NetMiner for Friendship developed by CYRAM. This program is compatible with Excel (spreadsheet) and it's easy to measure 
various centrality in each segment that are generated through the graphing phase of the network, the degree of interacting with other participants, participants' intimacy with other participants, and it creates a sociogram based on interaction (chart human relationships within a group and group structure).

Questionnaire survey results using Excel Program construct matrix $(\mathrm{n} \times \mathrm{n})$ about a nominating student in the Source area and about a nominated student in the Target area. In this study, directed graph was expressed in the relationship between friends and at the same time in the direction of relationship (Kim \& Kim, 2010). In directed graph, the direction of the relationship was drawn with arrows. Visualized contents is represented on the top of a graph about each participant and direction lines means the interaction between participants. Visualizations of the network vividly visualize the dynamics of the classroom and additional relationships more clearly than any other method, and provide a meaningful assistant way for measuring social groups with self-information transmission (Doran et al., 2011).

With NetMiner 4.0, the entire network changes measured the density which means how many relationships the entire members in the network have. The individual locations within the network was understood through analysis of degree centrality, closeness centrality, betweenness centrality about the degree of relationship between different members. In social network analysis, the characteristics of these were organised as shown in Table 3.

\begin{tabular}{|l|l|}
\hline Analysis contents & \multicolumn{1}{|c|}{ Features } \\
\hline Density & $\begin{array}{l}\text { Shows the degree of connectivity among the doers on the network } \\
\text { Ratio of number of all connectable connection lines and actually connected lines } \\
\text { A concept that describes how perfectly a subgroup is constructed } \\
\text { Density has a value of 0-1 and the density of a diagram with all points connected all is } 1 .\end{array}$ \\
\hline Degree centrality & $\begin{array}{l}\text { Measure how many connections nodes on the network have } \\
\text { The more the number of nodes connected with it, the higher degree centrality is } \\
\text { In-degree is frequency indicated as a target of activity from other organizations, receiver } \\
\text { Out-degree is frequency of jointly external activities requested by each organization, } \\
\text { transmitter }\end{array}$ \\
\hline Closeness centrality \\
$\begin{array}{l}\text { Measure the distance between the two nodes by looking at how much a node is closest to } \\
\text { another node } \\
\text { The smaller the value of combining the connecting distance that reach the other nodes in } \\
\text { the network, the higher the proximity of that node is } \\
\text { The higher the closeness centrality of the nodes is, the nodes are located in the center of the } \\
\text { network } \\
\text { Calculation of combining the length of the shortest distance from an doer to all other doers }\end{array}$ \\
\hline $\begin{array}{l}\text { The extent to performing as a broker or a bridge role about how many networks in other } \\
\text { points One point is connected with } \\
\text { A high betweenness centrality group is a central organization that promotes jointly external } \\
\text { activities among other organizations. } \\
\text { Many class members with higher betweenness centrality is a great help to the integration of } \\
\text { classes. }\end{array}$ \\
\hline
\end{tabular}

Table 3. Social Network Analysis Contents and Features

In addition, with NetMiner for Friendship, The relationships of the class (the number of all the students, the number of solitary selecting students, the number of isolated students, Relationship density, average number of friends, connection), current situation of friendship (the most chosen student, solitary selecting students, isolated students), current situation of friends group, map of relationshhip were analyzed.

The researcher of this study has analyzed the communication network inside the group by using NetMiner for Friendship, and the communication network indicates the structure of communication 
channels between organization members, further meaning interaction patterns that connect all the organization members with one another.

The communication process within the organisation connects a transmitter and a receiver directly, but communication in organisations or groups often involves multiple communication networks. Today, researchers propose five types of communication networks that assumed five members. Leavitt (1951) analyzed the type of doers that are located centrally in five communication networks, and the features of each type are like Table 4.

Bavelas and Barrett (1951) summarized that using the criteria of immediacy of communication, accuracy of communication, probability that the leader appears spontaneously, group members' satisfaction, a central member, and problem solving speed and so on, the validity of the communication network are evaluated and the study results were summarized in Table 5.

\begin{tabular}{|c|c|}
\hline Type & Features \\
\hline \multirow{7}{*}{ Chain type } & $\begin{array}{l}\text { Chain Type is a case that communication is flown not between group members who have similar } \\
\text { ranks or positions but only between superiors and inferiors in the group. }\end{array}$ \\
\hline & $\begin{array}{l}\text { In group expressly formulated by the organization for formal instructions and authority, it is a } \\
\text { network that allows communication only through a vertical layer. }\end{array}$ \\
\hline & $\begin{array}{l}\text { In the case of vertical type, all information is collected and reported to the central figure, on the } \\
\text { contrary. the instructions are delivered from the top to the bottom. In this case, if the chain is longer, } \\
\text { the likelihood of information distortions is greater, and this type is largely located in a bureaucracy. }\end{array}$ \\
\hline & $\begin{array}{l}\text { The horizontal form is the case where information is transferred to the left and right, and the } \\
\text { member in the middle of a group becomes a central figure. }\end{array}$ \\
\hline & $\begin{array}{l}\text { In horizontal format, the movement and collection of information are slow, and thus the speed of } \\
\text { the problem are slow, and the satisfaction of members in the team are low. }\end{array}$ \\
\hline & $\begin{array}{l}\text { Collection of information and thus the speed of the problem are relatively slow, and the satisfaction } \\
\text { of members who are located nearby are relatively low except those located in the middle. }\end{array}$ \\
\hline & $\begin{array}{l}\text { Mutual feedback is complex and difficult, and the communication between members is not fully } \\
\text { connected. }\end{array}$ \\
\hline \multirow{4}{*}{ Y type } & $\begin{array}{l}\text { Y Type is a case that a communication network appears when there is a figure representing a } \\
\text { relatively great number of members in the group. }\end{array}$ \\
\hline & Y shape shows communicating through four layers \\
\hline & $\begin{array}{l}\text { This is communication pattern that exists a leader representing a majority of members without a } \\
\text { solid center figure's existence. }\end{array}$ \\
\hline & There is a relatively strong centrality. \\
\hline \multirow{3}{*}{ Wheel type } & $\begin{array}{l}\text { Wheel Type is a case that a central figure or a leader exists in the group, so information between } \\
\text { group members is intensively delivered to the one person. }\end{array}$ \\
\hline & $\begin{array}{l}\text { Information can be gathered quickly and a central figure can synthesize information. and it is the } \\
\text { advantage of exact situation awareness and speedy problem solving. }\end{array}$ \\
\hline & $\begin{array}{l}\text { While the nature of the problem is simple and excellent in everyday life, and its merits fail to } \\
\text { materialize when problems are complex and difficult to solve. }\end{array}$ \\
\hline \multirow[t]{5}{*}{ Circle type } & $\begin{array}{l}\text { Circle Type is a case that a communication network is formed when group members communicate } \\
\text { with one another in almost the same position since there is no clear difference in rank or position } \\
\text { between them. }\end{array}$ \\
\hline & $\begin{array}{l}\text { Since the atmosphere is free and the members' interaction is not biased, the circular communication } \\
\text { network is likely to form. }\end{array}$ \\
\hline & $\begin{array}{l}\text { As a communication type, there is no centrality of power, and there is no hierarchy of positions of } \\
\text { rank, higher or lower rank. }\end{array}$ \\
\hline & $\begin{array}{l}\text { It has the advantage of the members' very high satisfaction because the process of problem-solving } \\
\text { is fairly democratic. }\end{array}$ \\
\hline & $\begin{array}{l}\text { Without the central character, information is passed between the members without the purpose of } \\
\text { communicating and communicating. }\end{array}$ \\
\hline
\end{tabular}




\begin{tabular}{|c|c|}
\hline Type & Features \\
\hline & $\begin{array}{l}\text { The disadvantage is that information transfer and collection, comprehensive understanding of } \\
\text { situations, and solving the problem and the lowest. }\end{array}$ \\
\hline \multirow{4}{*}{$\begin{array}{l}\text { All channel } \\
\text { type }\end{array}$} & $\begin{array}{l}\text { All-channel Type is a case that a communication network is formed when every group member can } \\
\text { freely communicated and exchange information with one another. }\end{array}$ \\
\hline & $\begin{array}{l}\text { Within a group, neither the leader nor the central character exists separately, so any member of the } \\
\text { group can lead to communications. }\end{array}$ \\
\hline & Simple day-to-day tasks or complex tasks can be solved at the same time. \\
\hline & $\begin{array}{l}\text { Because everyone is exchanging information, it takes a lot of time to understand and solve the } \\
\text { problem, but it is more likely that creative ideas will come, and solving a difficult problem is the most } \\
\text { effective and satisfactory. }\end{array}$ \\
\hline
\end{tabular}

Table 4. Features of Communication Network Type

\begin{tabular}{|l|c|c|c|c|c|}
\hline \multirow{2}{*}{\multicolumn{1}{|c|}{$\begin{array}{c}\text { Criteria of } \\
\text { assessment }\end{array}$}} & \multicolumn{5}{|c|}{ Communication Networks Type } \\
\cline { 2 - 6 } $\begin{array}{l}\text { Immediacy of } \\
\text { communication }\end{array}$ & middle & Y type & Wheel type & Circle & All channel \\
\hline $\begin{array}{l}\text { Accuracy of } \\
\text { communication }\end{array}$ & high & high & high & low & fast \\
\hline $\begin{array}{l}\text { Probability that the } \\
\text { leader appears }\end{array}$ & middle & middle & high & none & none \\
\hline $\begin{array}{l}\text { Group members } \\
\text { satisfaction }\end{array}$ & middle & middle & low & high & high \\
\hline A central member & $\begin{array}{c}\text { Vertical (above) } \\
\text { Horizontal (middle) }\end{array}$ & central & central & none & all \\
\hline $\begin{array}{l}\text { Problem solving } \\
\text { speed }\end{array}$ & $\begin{array}{c}\text { Vertical (low) } \\
\text { Horizontal (low) }\end{array}$ & fast & fast & slow & slow \\
\hline
\end{tabular}

Table 5. Evaluation of Communication Networks (Bavelas \& Barrett, 1951)

\section{Discussion and Conclusion}

\subsection{Analysis Result of Friendship by Social Network Analysis}

In class, analysis results of density, degree centrality, closeness centrality, and betweenness centrality through the results of the student response to the questionnaire about "Would it be helpful to have a discussion with someone in science class?" are like Table 6.

In the network, the density refers to the degree of connection between the network nodes and the number between 0 and 1, and expressed as the number of nodes. Increased density in post-test compared to pre-test indicates nodes means that the connection between nodes has become numerous and there's more interaction between them and it is closely connected to form a complex structure.

\begin{tabular}{|l|l|r|r|}
\hline \multicolumn{2}{|c|}{ Analysis Content } & $\begin{array}{c}\text { Before Scientific Class applying } \\
\text { STAD Learning }\end{array}$ & $\begin{array}{c}\text { After Scientific Class applying } \\
\text { STAD Learning }\end{array}$ \\
\hline Density & 0.117 & 0.138 \\
\hline $\begin{array}{l}\text { Degree } \\
\text { centrality }\end{array}$ & In-centrality & 0.117 & 0.138 \\
\cline { 2 - 5 } $\begin{array}{l}\text { Closeness } \\
\text { centrality }\end{array}$ & Out-centrality & 0.117 & 0.138 \\
\cline { 2 - 5 } In-centrality & Out-centrality & 0.32 & 0.361 \\
\hline \multicolumn{2}{|l|}{ Betweenness centrality } & 0.314 & 0.357 \\
\hline
\end{tabular}

Table 6. Analysis Result of Social Network Analysis 
In case of degree centrality, in-centrality and out-centrality increased after Scientific Class applying STAD Cooperative Learning, and prior and post of in-centrality and out-centrality shows the same figures respectively. This means the average of the connection relationships between members within the group and in-degree and out-degree are balanced (Kim \& Park, 2008). While out-degree takes into account only the relationships from one node to another, in-degree consider relationships only from another to one node. With higher in-degree, the student can be considered to be more popular among other students, but with higher out-degree, the student can be considered to have more effect on other students. As a result, degree centrality increased in post-test and there are frequently more direct connections between members within the class. Yet, Degree Centrality is measured with the ratio of each doer's in-degree and out-degree out of the entire number of connections.

Since closeness centrality increased and It provided indicators that show the relative degree of entire closeness in the group, or the relative closeness degree of the various members within the group, and among the group members (Doran et al., 2011), this means that when interacting with various members, the distance to other members of the group shorten (Kim \& Noh, 2010). Through the Cooperative Learning study, there was a lot of internal and external exchanges between members of the group, which meant that they had to interact directly with the various members. Increased closeness centrality means that it's easy to get close to other students and easily relate to them, and it means that a growing number of students played a central role with a relatively strong possibility of influencing their peers effectively.

Based on betweenness centrality through indirect or direct interaction within the network, how high levels of relationships an individual is associated with others is quantified. The inspection results also showed the increase of parameters between members of the group. This means in the information flow and exchange between the entire network members after Scientific Class applying STAD Cooperative Learning, significant increase in students who play an important role in the network and act as mediators. Through this, it was judged that it tended to better socialize with all participants and interact with other highly active participants.

The relational index of the whole class is shown in Table 7. Prior to the test, the number of students who were not indicated by other students was seven, but after posttests, all the students were indicated once and none of the students had any relationships with other students. The relationship density refers to the degree of friendship in class and it appears to be between 0 and 1 , which if everybody is connected to each other, it becomes one and if nobody is connected, it becomes zero. Overall, the relationship density was found to be low in pre-test, but slightly higher in post-test. The average number of friends was similar to 3.4 in pre-test, and in post-test 3.976. It was noted that the reason of the questionnaire of writing up to four close friends resulted in a similar number. Last, a value that all the students in the class are not isolated and but connected is between 0 and 1 , and 1 in post-test means that all students are connected without isolation.

Students who do activities in group through STAD Cooperative Learning are expected to make a selection within a group, but by watching the actual activities of the other teams, the name of co-workers who become members of the same group are often written down. Namely, STAD activity is judged to provide a wide range of opportunities to broaden the relationship between friends.

\begin{tabular}{|c|c|c|c|c|c|c|}
\hline & $\begin{array}{c}\text { Total } \\
\text { number of } \\
\text { students }\end{array}$ & $\begin{array}{l}\text { Number of } \\
\text { students } \\
\text { selected } \\
\text { alone }\end{array}$ & $\begin{array}{l}\text { Number of } \\
\text { isolated } \\
\text { students }\end{array}$ & $\begin{array}{l}\text { Relationshi } \\
\text { p density }\end{array}$ & $\begin{array}{l}\text { Average } \\
\text { number of } \\
\text { friends }\end{array}$ & $\begin{array}{c}\text { Connection } \\
\text { degree }\end{array}$ \\
\hline $\begin{array}{l}\text { Before Scientific Class } \\
\text { applying STAD Learning }\end{array}$ & 30 & 7 & 0 & 0.117 & 3.4 & 0.582 \\
\hline $\begin{array}{l}\text { After Scientific Class } \\
\text { STAD Learning }\end{array}$ & 30 & 0 & 0 & 0.137 & 3.967 & 1 \\
\hline
\end{tabular}

Table 7. The Relational Index of the Class 
Also, this results are similar with the study of Koo and Kim (2011) that a feeling of kindness toward one's colleagues which students are aware of are much higher after STAD Cooperative Learning than before STAD Cooperative Learning, and the study of Khan and Inamullah (2011) that interrelations in the classroom have a strong positive effect on students' social development through STAD Cooperative Learning.

Lee and Yoo (2003) suggested that a typical classroom strategy that naturally leads to active interaction among students is STAD Cooperative Learning. Koo and Kim (2011) told that through cooperative learning methods, students learned social skills such as leadership, conflict resolution ability, and communication skills, and learned to trust each other. Mittelmeier, Heliot, Rienties and Whitelock (2016) said that when participating in collaborations through cooperative learning, students can form positive social relations with more various colleagues. In addition, STAD Cooperative Learning developed improving cooperative relationships between cooperative relationships and mutual relationships among friends, and these days, prevent problems of school bullying, school violence, school violence, and so on. It is encouraging to form a positive and cheerful friendship, which can provide significant meaning to the interactive problem among peers in schools. In particular, scientific activity can lead to meaningful results through group activities, and STAD Cooperative Learning is an important teaching method of learning science.

\subsection{Results of Popularity Analysis Conducted by Social Network Analysis}

In Table 8 to identify popularity, the top five ranked students of centrality was shown through the analysis of class social networks.

In degree centrality, the high value in the centrality was shown in S24 and S2, and then a similar value was shown in S15, S8, and S14. That is to say, that means that they are chosen to have relationships with other students, and in that the need to establish relationships with other actors is high, they are regarded as a high prestige member (Park \& Choi, 2011). Moreover, it means that efforts to connect with others are active, and means that there is a wide range of network deployments (Park \& Choi, 2011).

Closeness centrality consists of in-centrality and out-centrality, the high value of in-centrality was shown in S24, S2, S8, S15, S14, and the high value of out-centrality was shown in S18, S28, S6, S7, S8. All the top students in closeness centrality including in-centrality and out-centrality were S8. It means that the network is built to allow other students to reach the student quickly, and It means that S8 unlike other students are linked to other students without a lot of other students.

The high value in betweenness centrality was shown in S2, S24, S14, S8, S5, and this shows that because various information flows into the path of introduction, they get new information early, so it's a crucial location for group interactions in inquiry activity.

Table 9 shows the phenomenon of friendship before and after science class applying STAD Cooperative Learning. In a similar result as the analysis results of centrality analyzed, the most selected students were S8, S24, S2, S14, S15, and in pre-test, seven students were not picked up by other students, but in post-test, all students were indicated. Members who were fully connected to each other were not found in advance, but seven groups were fully connected to each other after the post-mortem examination.

Figures 1-2 are relationships maps of pre-test and post-test. In the map, the centrality of the arrow focusing on S8, S14, S2, S24, and S15 was confirmed, and there is a intensely close relationship with friends in the middle of the map. As a result, relationship analysis based on social networking analysis could be used as a basic data to solve the problem of bullying in Korea, which has emerged as a serious problem in recent years.

S8, S24, S2, S14 has high value in betweenness centrality, and thus serves as a key hub. They say that they have relatively large social capital compared to other students. At this point, social capital means stable relationships between people (students) that they can get various sorts of information. In common, they 
were engaged actively in inquiry activities, as evidenced by the student interviews or interviews of teachers (Table 10). They encouraged members to actively participate in group's inquiry activity and gave kindness to members excluded from the group. Along with the willingness to help others and cooperate with each other, they also had the characteristics of high academic achievement. Rather than a teacher's unilateral study atmosphere, the horizontal learning atmosphere are more effective of establishing friendships (Kim \& Yoo, 2012). Also, because students who have good grades in school are more receptive of their positive interaction with their classmates, the preceding study emphasized school grades as important measures for student's social skills. So When a group assembled in science class, type of the leader were identified, If a group was organized and science class was conducted, it is believed that students will be able to expect a positive change in their academic achievement, problem-solving problems and positive changes in learning.

\begin{tabular}{|c|c|c|c|c|c|}
\hline \multirow{2}{*}{ Ranking } & \multicolumn{4}{|c|}{ After five weeks of class applying STAD Cooperative Learning } \\
\cline { 2 - 5 } & \multicolumn{2}{|c|}{ Degree centrality } & \multicolumn{2}{c|}{ Closeness centrality } & \multirow{2}{*}{$\begin{array}{c}\text { Betweenness } \\
\text { centrality }\end{array}$} \\
\cline { 2 - 5 } & In-centrality & Out-centrality & In-centrality & Out-centrality & S2(0.263887) \\
\hline 1 & $\mathrm{~S} 24(0.344828)$ & $\mathrm{S} 24(0.137931)$ & $\mathrm{S} 24(0.537037)$ & $\mathrm{S} 18(0.426471)$ & $\mathrm{S} 2(0.521034)$ \\
\hline 2 & $\mathrm{~S} 2(0.275862)$ & $\mathrm{S} 2(0.137931)$ & $\mathrm{S} 2(0.537037)$ & $\mathrm{S} 28(0.420290)$ & $\mathrm{S} 24(0.210934)$ \\
\hline 3 & $\mathrm{~S} 15(0.241379)$ & $\mathrm{S} 15(0.137931)$ & $\mathrm{S} 8(0.460317)$ & $\mathrm{S} 6(0.420290)$ & $\mathrm{S} 14(0.177519)$ \\
\hline 4 & $\mathrm{~S} 8(0.241379)$ & $\mathrm{S} 8(0.137931)$ & $\mathrm{S} 15(0.426471)$ & $\mathrm{S} 7(0.420290)$ & $\mathrm{S} 8(0.148763)$ \\
\hline 5 & $\mathrm{~S} 14(0.241379)$ & $\mathrm{S} 14(0.137931)$ & $\mathrm{S} 14(0.426471)$ & $\mathrm{S} 8(0.408451)$ & $\mathrm{S} 5(0.127381)$ \\
\hline
\end{tabular}

Table 8. Top Ranked Student by Central Indicators

\begin{tabular}{|c|c|c|c|}
\hline & $\begin{array}{c}\text { Most Chosen Students } \\
\text { (Indicated Number) }\end{array}$ & $\begin{array}{c}\text { Students who are not picked } \\
\text { up by other students }\end{array}$ & $\begin{array}{c}\text { Group (all members who are } \\
\text { fully connected to each other } \\
\text { More than 3) }\end{array}$ \\
\hline Pre-test & S8(10), S24(8), S2(8), S14(8) & S30, S17, S12, S26, S4, S1, S19 & None \\
\hline & & & Group1(s11, s13, s15) \\
& & & Group2(s14, s13, s15) \\
& Group3(s5, s2, s3) \\
Post-test & S24(8), S2(8), S15(7), S8(7), & None & Group4(s1, s2, s3) \\
& S14(7) & & Group5(s21, s22, s23, s24) \\
& & & Group6(s21, s22, s23, s25) \\
& & & Group7(s12, s13, s15) \\
\hline
\end{tabular}

Table 9. Friendship Before and After Science Class Applying STAD Cooperative Learning

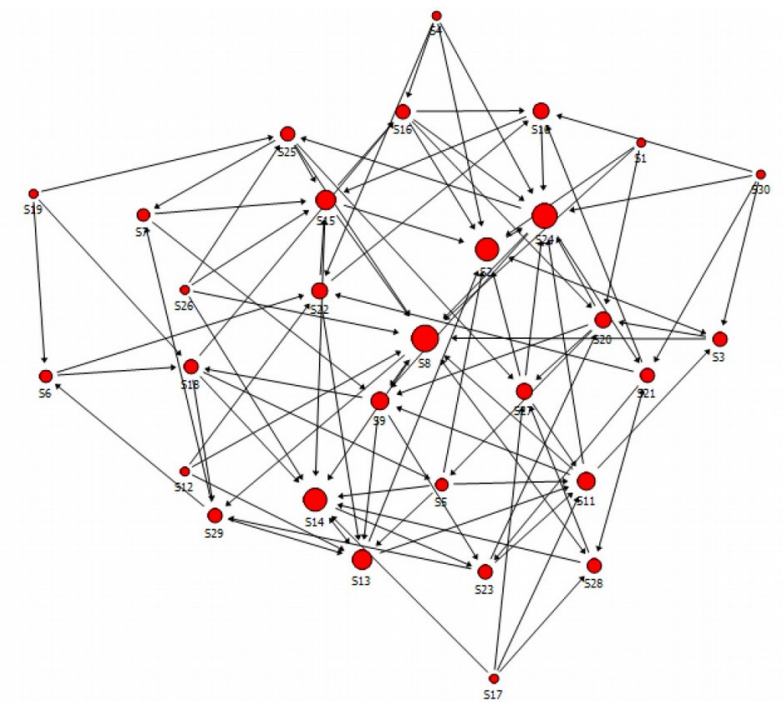

Figure 1. Relationships Maps of Pre-Test 


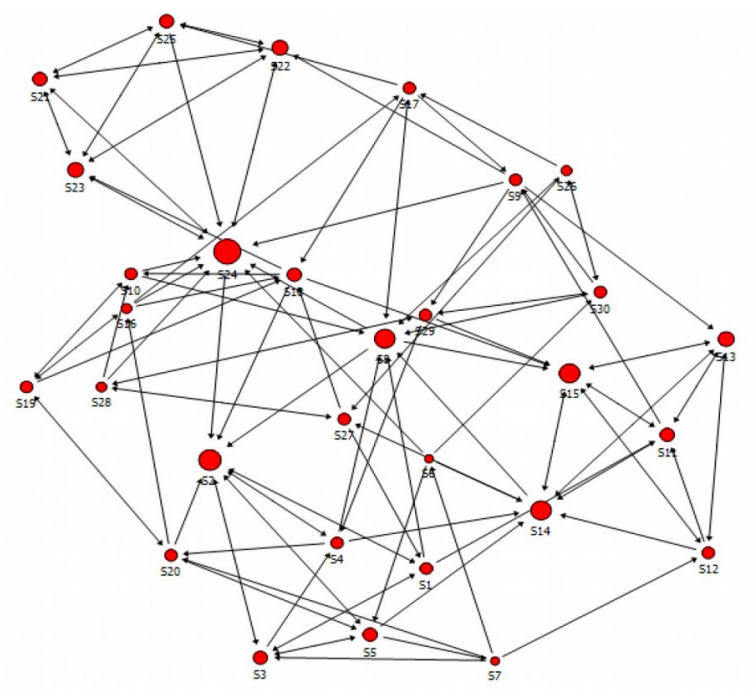

Figure 2. Relationships Maps After Class

\begin{tabular}{|c|c|c|}
\hline Students & Reason pointed out by fellow students & Teacher interview content \\
\hline S24 & $\begin{array}{l}\text { S24 performed Good design. } \\
\text { S24 is good at feedback on the results of } \\
\text { experiments. } \\
\text { S24 has creative ideas } \\
\text { Especially, S24 is interested in scientific } \\
\text { phenomenon. } \\
\text { S24 understands the intention of the science } \\
\text { teacher. }\end{array}$ & $\begin{array}{l}\text { S24 student has excellent academic ability, and } \\
\text { recently conducted an inquiry function test. S1 got } \\
\text { the best score in class, and other friends were very } \\
\text { jealous. S1 worked very aggressively to try to solve } \\
\text { the challenge. }\end{array}$ \\
\hline S2 & $\begin{array}{l}\text { S2 leads the team well. } \\
\text { S2 is a friend who can share roles. } \\
\text { S2 is a friend who respects his colleague's opinion. } \\
\text { S2 is a child who can supplement his opinion with } \\
\text { a friend. } \\
\text { S2 is a bright student. }\end{array}$ & $\begin{array}{l}\text { S2 student is a class president. That's why S2 has } \\
\text { great leadership skills. S2 is considerate of other } \\
\text { students and cares about others. Even in science } \\
\text { class, S2 ask considerate questions for friends and } \\
\text { present a lot of opinions that support friends' } \\
\text { opinions. }\end{array}$ \\
\hline S15 & $\begin{array}{l}\text { S15 has much knowledge of science. } \\
\text { S15 has a lot of new information about science. } \\
\text { S15 teaches well. } \\
\text { S15 is a model student. }\end{array}$ & $\begin{array}{l}\text { S15 is always ranked first in science grade of the } \\
\text { class. } \\
\text { S15 reads many books about science and solves } \\
\text { questions about other students as a mentor. }\end{array}$ \\
\hline S8 & $\begin{array}{l}\text { S8 is bright and has lack of skills on difficult } \\
\text { speech which friends do, but present confidently. } \\
\text { S8 is actively engaged in experiments. } \\
\text { S8 is well prepared for experiments. } \\
\text { S8 has a positive mind. }\end{array}$ & $\begin{array}{l}\text { S8 is a middle grade in science, but very active. S8 } \\
\text { actively participates in expressing opinions and } \\
\text { tries to understand what S8 doesn't know. }\end{array}$ \\
\hline S14 & $\begin{array}{l}\text { S14 is thorough. } \\
\text { S14 writes down the experiment report well. } \\
\text { S14 make a clear presentation } \\
\text { S14 is a friend who clearly disposes of the results } \\
\text { of the experiment. }\end{array}$ & $\begin{array}{l}\text { S14 is good at writing science. } \\
\text { S14 writes in science assignments logically and } \\
\text { systematically. } \\
\text { S14 understands the point of the problem and } \\
\text { clear out the topic and arguments neatly. }\end{array}$ \\
\hline
\end{tabular}

Table 10. Characteristics of Students with High Values of Centrality

Because scientific learning is a result of ideas' discussion through interaction and it is affected by learners' interaction, activities that are premised on active interactions have important implications for science learning (Park \& Shin, 2012). In this educational context, cooperative learning develops new concepts through interaction, suggesting solutions, cultivating a high level of reasoning, and information and 
knowledge in one context, and it is a representative science learning strategy that can lead to achievement of the group and achievement of the individual (Roger \& Johnson, 1994).

\subsection{Analysis of the Communication Network Type Within a Group}

When a question about "Would it be helpful to have a discussion with someone in a group within a group?" was asked to identify six group's communication networks changes through STAD cooperative learning, the change in the pre-test, and post-test of network type is like Table 11. Figure 3-7 is a map of five types of network types.

Before class applying STAD cooperative learning, 1 group has chain type, and 1 group has Y type, and 1 group has wheel type, but after class 1 group has $\mathrm{Y}$ type, and 1 group has circle type, and 1 group has all channel type. In other words, there has been a lot of changes in all channel type through STAD cooperative learning.

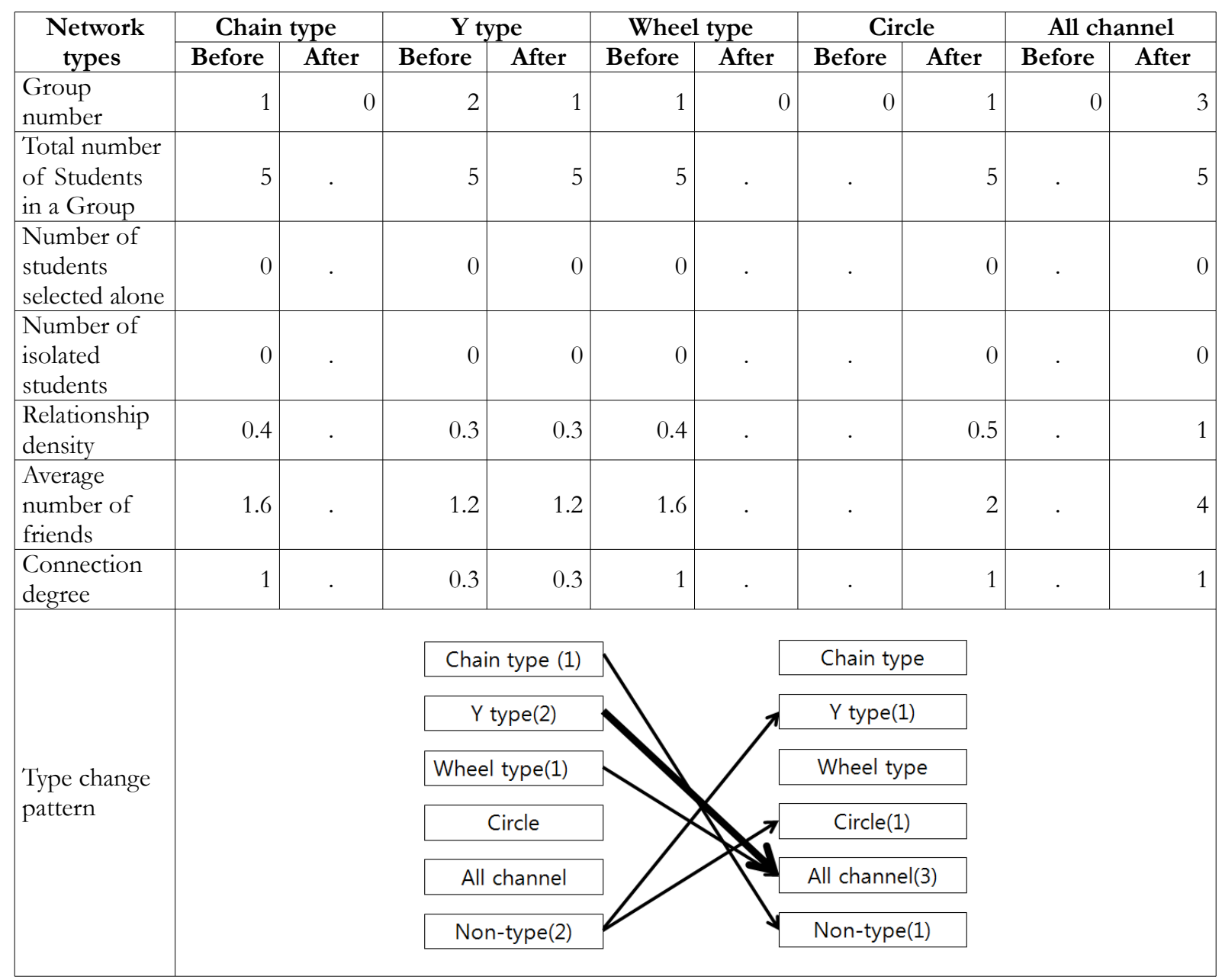

Table 11. Change of communication network types within groups before and after Science classes in STAD Cooperative Learning 


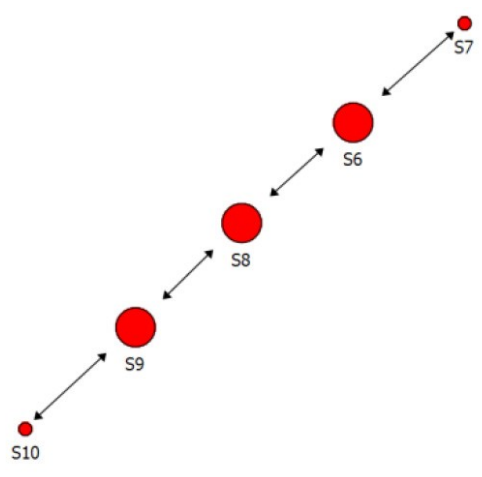

Figure 3. Before class-Chain type

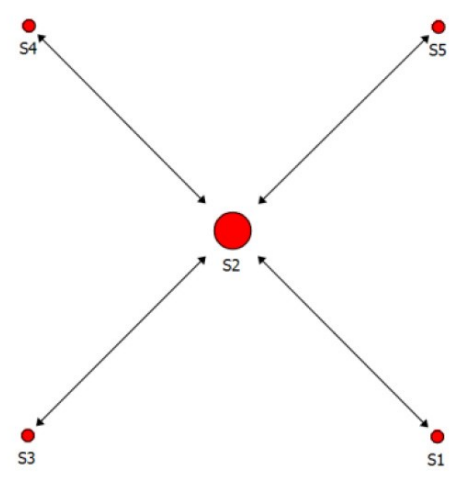

Figure 4. Before class-Wheel type

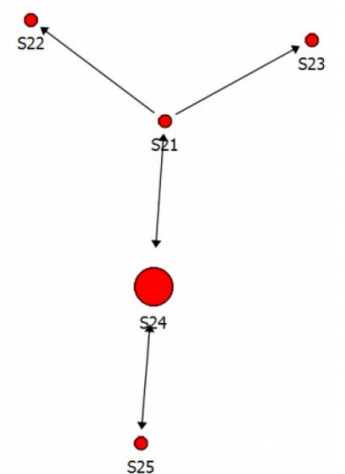

Figure 5. Before class-Y type

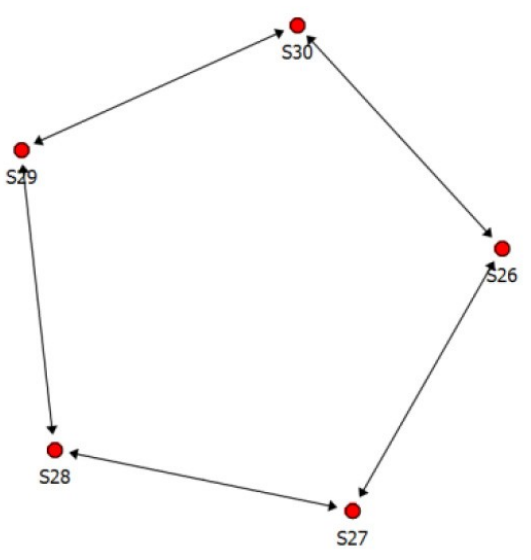

Figure 6. After class-Circle

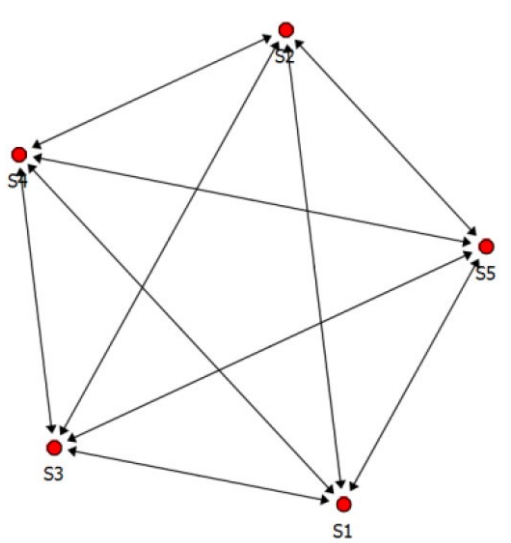

Figure 7. After class-All channel

Because chain type is a type to communicate through one way direction in relation of group members and the outcome of the group's performance is highly likely to be controlled by the decision of a group of highly concentrated members within the group and feedback from members' opinion is not returned, chain type is not appropriate for STAD cooperative learning (Kim \& Park, 2008). On the other hand, because wheel type is suitable in organizations that perform simple tasks for usually faster decision-making, wheel type is good at saving time and limiting communication by virtue of the boss's competence. In organizations that require creative solutions or focus on complex tasks, all channel and circle is proper for a lot of communication and for sharing information within groups.

In particular, all channel and circle has a characteristic of exchange many messages among group members and high satisfied feeling and enjoying in group activities. In case of all channel and circle type, because opinions that members suggest returned through another member, everyone is able to participate in activities to variously communicate with all members without being left unattended. Also, all channel type increases the cohesion within the group, and is better receptive of group members, and classroom atmosphere becomes more open, sympathetic and supportive system (Jung, Lee \& Jeong, 2009). As a group composed of all-channel type communication networks is defined as a single complete social group, students in such a group can jointly achieve learning goals through simultaneous interaction, equal participation and idea sharing (Crespo \& Antunes, 2012). In other words, it is possible to increase all channel and circle type by conducting a STAD cooperative study because of a feeling of satisfaction and the atmosphere of enjoying the activity among group members through frequent communication among members of the group. Also, after STAD cooperative learning, no chain type appeared and all channel and circle type increase, which can be interpreted as a result of increased communication efficiency. Of course, in all channel and circle type, there is a lot of errors because of the difficulty of solving problems and reflecting the opinions of all members, but a cooperative learning that focuses on achievement of processes and common goals can lead to positive learning effects through the learning process of these trials and errors (Kim \& Park, 2008). 


\section{Conclusion and Suggestion}

The aim of this study was to analyze Studs' relationship, the characteristics of the popular students and the type of communication network within the group by science learning applying STAD cooperative learning through social network analysis methods.

Research method is a questionnaire using NGQ, and NetMiner 4.0 and NetMiner for data processing were utilized.

The conclusions derived from research methods and results are as follows:

First, the class social network analysis showed that all the prices of density, degree centrality, closeness centrality, and betweenness centrality have risen after science class applying STAD Cooperative Learning. Also, the classroom's relationship index has improved. In particular, since the connection value is 1 after class than before the class in the connection degree, which means a connection to all students, STAD Cooperative Learning encouraged interaction among students.

These results show that although it is not easy of individual teaching in overcrowded class, when a group is organized with consideration of intimacy with the best friends in the classroom through STAD Cooperative Learning, the team can discuss each other satisfactorily and ask questions and answer each other comfortably, which learning motivation is also improved and learning ability is expected to increase naturally.

Second, in order to research popularity, students' centrality analysis through the class social network analysis showed that even though the indicators' values of density, degree centrality, closeness centrality, and betweenness centrality were different, the top five ranked students were the same. Students in the fifth ranking also seem to be central to the relation map and play a central role in the interaction. They were able to connect to many colleagues and lead to information flow or decision making. In the survey and teacher interviews, it was analyzed they were actively engaged in inquiry activities and had a considerate attitude toward peer.

Especially within the framework of a structural paradigm focusing on the development environment for both interpersonal and social skills, there should also be a practical use of these students in that they play a central role in learning.

Overall, by examining changes in popular students after STAD cooperative learning was applied to science class, this study discovered a possibility that it could be used as a bullying problem-solving learning method. Moreover, by analyzing popular students' features on the communication network and their behavioral characteristics in actual group activities, this study found out what roles popular students played and even provided meaningful implications on teachers' group activity-based science class.

Third, the analysis of the communication network change within six groups applying STAD Cooperative Learning turns out that it increased cohesion within the group through all channel type, and exchanging information freely with all members and the process of resolving the problem shared by democratic members of the group through circle type. When all channel type has the characteristics of groups required by cooperative learning, the increase of all channel type through STAD Cooperative Learning can be seen as an important reminder of scientific learning.

The results of this study can be summarized as below. Since STAD cooperative learning helped activate interactions between all students in the same group, and inquiry activities play an important role in science class, it is necessary to apply STAD cooperative learning when students carry out inquiry activities. Besides, as group activities are activated mainly by students who are considerate of others and actively participate in inquiry activities, it is important to make the best use of such students and create an atmosphere that all the students can interact with one another and participate in inquiry activities without anyone alienated from the group. 
Based on the conclusion of this study, the suggestions about science education and follow-up studies are as follows.

First, in terms of the significance of this study, the subject, scope and learning chapter of this study is somewhat limited to the generalization of the findings. To identify or evaluate the characteristics of a generalized friendship, it is necessary to review students' interactions with various scientific subjects and analyze the social networks among more participants.

Second, this study showed that STAD Cooperative Learning through social networking analysis could positively affect relationships with friends. Therefore, it is also important to suggest ways to improve friendships in science classes through various teacher training workshop on teahcers' proper comprehension and the use of STAD Cooperative Learning. In addition, Ruane and Koku (2014) insisted that when a teacher makes an on-line learning space and provides a chance for students to communicate and cooperate with one another, it will be effective in improving their peer relations. Therefore, it is necessary to develop and actively utilize on-line learning programs for cooperative learning in science class.

\section{Declaration of Conflicting Interests}

The author declared no potential conflicts of interest with respect to the research, authorship, and/or publication of this article.

\section{Funding}

The author received no financial support for the research, authorship, and/or publication of this article.

\section{References}

Bavelas, A., \& Barrett, D. (1951). An experimental approach to organizational communication. Personnel, 27, 366-371.

Cho, H., Lee, J.S., Stefanone, M., \& Gay, G. (2005). Development of computer-supported cooperative social networks in a distributed learning community. Behaviour \& Information Tecbnology, 24(6), 435-447. https://doi.org/10.1080/01449290500044049

Choi, C. (2011). Usage research methodology. Seoul, South Korea: HAKHYEONSA.

Crespo, P., \& Antunes, C. (2012). Social Networks Analysis for Quantifying Students' Performance in. Teamwork. In: Proceedings of the 5th International Conference on Educational Data Mining (234-235).

Dawson, S. (2008). A study of the relationship between student social networks and sense of community. Educational Technology \& Society, 11(3), 224-238.

Doran, R., Doran, C., \& Mazur, A. (2011). Social network analysis as a method for analyzing interaction in cooperative online learning environments. Systemics, Cybernetics and Informatics, 9(7), 10-16.

Freeman, L. (2000). Visualizing social networks. Available at: http://www.cmu.edu/joss/content/ articles/volume1/Freeman.html (Accessed June 2017)

Haythornthwaite, C. (2002). Building social networks via computer networks: Creating and sustaining distributed learning communities. In Renninger, K.A., \& Shumar, W. (Eds.), Building virtual communities: Learning and change in cyberspace (159-190). New York: Cambridge University Press.

Huh, N., \& Lee, S. (2010). An impact of communication networks on group cohesiveness under uncertainty. Korean Corporation Management Review, 17(1), 163-184. 
Jung, M., Lee, J., \& Jeong, Y. (2009). The effects of group horticulture activity of herb plant on the improvement of peer relation and a class cohesion in the lower grades elementary students. Journal of Korean Practical Arts Education, 22(3), 107-124.

Karaçöp, A. (2016). Effects of student teams-achievement divisions cooperative learning with models on students' understanding of electrochemical cells. International Education Studies, 9(11), 104-120.

https://doi.org/10.5539/ies.v9n11p104

Khan, G.N., \& Inamullah, H.M. (2011). Effect of student's team achievement division (STAD) on academic achievement of students. Asian Social Science, 7(12), 211-215.

https://doi.org/10.5539/ass.v7n12p211

Kim, C., \& Kim, W. (2010). The analysis between sports participation of adolescent and social network of a classroom. Korean Society for the Sociology of Sport, 23(1), 45-67. https://doi.org/10.22173/jksss.2010.23.1.45

Kim, D. (2007). An analysis and improvement plans regarding students' recognition towards sex: related to a high-school science "reproduction" unit. The Journal of Education Research, 28(2), 78-98.

Kim, D., \& Yoo, J. (2012). The analysis on social status of college students with developmental disabilities through peer nomination and social network preferred students and rejected students. Journal of Special Education: Theory and Practice, 13(4), 27-54. https://doi.org/10.19049/JSPED.13.4.02

Kim, H., \& Noh, J. (2010). A study on the change of youth peer network: focusing on the life competency. Journal of Future Oriented Youth Society, 7(2), 87-109.

Kim, M., Chu, C., \& Kim, Y. (2011). An analysis of understanding aspects required by teachers and perceived by students in the "reproduction and genesis" unit. Journal of the Korean Association for Research in Science Education, 31(4), 600-608.

Kim, M., \& Park, H. (2008). The social network analysis on interdependence and group types in web-based cooperative learning. The Korean Journal of Educational Methodology Studies, 20(1), 155-172.

Koo, B., \& Kim, J. (2011). The effects of peer relationships on physical education classes through the application of the STAD cooperative learning model. Journal of Research in Curriculum Instruction, 15(1), 185-202. https://doi.org/10.24231/rici.2011.15.1.185

Leavitt, H.J. (1951). Some effects of certain communication patterns on group performance. The Journal of Abnormal and Social Psychology, 46, 38-50. https://doi.org/10.1037/h0057189

Lee, Y., \& Yoo, J. (2003). Effect of gender grouping on cooperative learning in middle school science. The Journal of The Korean Earth Science Society, 24(3), 141-149.

Maelasari, E., \& Wahyudin, M.T. (2017). Effects of Cooperative Learning STAD on Mathematical Communication Ability of Elementary School Student. International Conference on Mathematics and Science Education. Conf. Series 895, 1-6. https://doi.org/10.1088/1742-6596/895/1/012090

Mittelmeier, J., Heliot, Y., Rienties, B., \& Whitelock, D. (2016) Using Social Network Analysis to predict online contributions: The impact of network diversity in cross-cultural collaboration. In:8th International ACM Web Science Conference. Hannover. https://doi.org/10.1145/2908131.2908169

Moreno, J.L. (1953). Who Shall Survive? Beacon, NY: Beacon House.

Park, E., \& Choi, M. (2011). The effect of learners' social network centralities on knowledge construction in online debating learning. Journal of Korean Association for Educational Information and Media, 17(3), 353-377. 
Park, M., \& Shin, Y. (2012). Analysis of linguistic interaction within a group according to leader's leadership in scientific inquiry activity in elementary school. Journal of the Korean Association for in Science Education, 32(4), 760-774. https://doi.org/10.14697/jkase.2012.32.4.760

Rai, N., \& Samsuddin, S. (2007). STAD Vs Traditional teaching, Redesigning Pedagogy-crpp conference. [Online] Available at: http://conference.nie.edu.sg/2007/paper/papers/STU349.pdf

Roger, T., \& Johnson, D.W. (1994). An overview of cooperative learning, creativity and Cooperative learning. Brookes Press Baltimore.

Ruane, R., \& Koku, E. (2014). Social network analysis of undergraduate education student interaction in online peer mentoring settings. Journal of Oline Learning and Teaching, 10(4), 557-589.

Slavin, R. (1978). Student teams and comparison among equals: Effects on academic performance and student attitudes. Journal of Educational Psychology, 70(4), 532- 538. https://doi.org/10.1037/00220663.70.4.532

Slavin, R.E. (1980). Cooperative learning. Review of educational research, 50(2), 315-342. https://doi.org/10.3102/00346543050002315

Slavin, R.E. (1990). Cooperative learning: Theory research and practice. Englewood Cliffs, NJ: Prentice Hall.

Sukma, T. (2013). The Effectiveness of Using STAD (Student Team Achievement Division) method In Teaching Reading Comprehension At The Fifth Grade student of SD N Kalinongko In the Academic Year 2012/2013. Pendidikan Bahasa Inggris, 1(2), 3-7.

Yang, J., Le, H., Oh, C., Jeong, J., Kwon, Y., \& Park, K. (2007). An analysis of social interaction according to students` preference for groups in science instruction of elementary school. Journal of Korean Elementary Science Education, 26(1), 1-11.

Vygotsky, L.S. (1978). Mind in society: The development of higher psychological processes (Cole, M., John-Steiner, V., Scribner, S., \& Souberman, E., trans.). Cambridge Mass: Harvard University Press.

Published by OmniaScience (www.omniascience.com)

Journal of Technology and Science Education, 2018 (www.jotse.org)

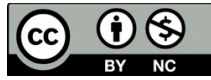

Article's contents are provided on an Attribution-Non Commercial 4.0 Creative commons International License. Readers are allowed to copy, distribute and communicate article's contents, provided the author's and JOTSE journal's names are included. It must not be used for commercial purposes. To see the complete licence contents, please visit https://creativecommons.org/licenses/by-nc/4.0/. 